\title{
IS Governance Evaluation Using COBIT 5 Framework on the Central Statistics Agency of Banyumas District
}

\author{
Rudy Yaniar Sianida ${ }^{1}$, Fiby Nur Afiana ${ }^{2 *}$, Rizki Wahyudi ${ }^{3}$ \\ ${ }^{1,2,3}$ Universitas Amikom Purwokerto, Jl. Letjend Pol. Soemarto, Karangjambu, Purwanegara, Kec. Purwokerto Utara, \\ Kabupaten Banyumas, Jawa Tengah 53127, Indonesia \\ rudysianida@gmail.com ${ }^{1}$, fiby@amikompurwokerto.ac.id², rizki.key@gmail.com ${ }^{3}$ \\ Corresponding Author*
}

\begin{tabular}{l}
\hline A R T I C L E I N F O \\
\hline Article History: \\
Received January 1, 2020 \\
Revised January 15, 2020 \\
Accepted February 10, 2020 \\
Available Online February 15, 2020 \\
Keywords: \\
COBIT 5, \\
Governance, \\
Capability, \\
Established Process
\end{tabular}

Kata Kunci:

COBIT 5,

Tata Kelola,

Kapabilitas,

Established Process

\section{Correspondence:}

Telephon: +62 85725619145

E-mail:

fiby@amikompurwokerto.ac.id

\begin{abstract}
The purpose of this study was to determine the level of capability at the Office of the Central Statistics Agency in Banyumas. Evaluate to find out how well the information system governance can operate at BPS that applies it to improve future performance. After evaluating, it is hoped that BPS will be able to produce higher-quality data because the government will use this data as a foundation for future development and as an evaluation of the results of development that have been carried out. The methodology used is a literature study, observation, interview, questionnaire and documentation by COBIT 5. The results achieved that the current BPS capability level is 3.25, which means it is at level 3 (established process). By being at level 3, BPS Office information system governance has been running well and has been able to achieve competitive and efficient business objectives of the agency in the use of information systems.

\section{ABSTRAK}

Tujuan penelitian ini ialah untuk mengetahui tingkat kapabilitas pada Kantor Badan Pusat Statistik Kabupaten Banyumas. Melakukan evaluasi untuk mengetahui seberapa baik tata kelola sistem informasi dapat beroperasi pada BPS yang menerapkannya untuk memperbaiki prestasi di masa mendatang. Setelah dilakukan evaluasi, diharapkan nantinya BPS bisa menghasilkan data yang lebih berkualitas, sebab data ini nantinya akan digunakan oleh pemerintah sebagai landasan pembangunan di masa yang akan datang serta sebagai evaluasi hasil pembangunan yang telah dilaksanakan. Metodologi yang digunakan ialah studi pustaka, observasi, wawancara, kuesioner dan dokumentasi yang sesuai dengan COBIT 5. Hasil yang dicapai bahwa tingkat kapabilitas BPS saat ini yaitu 3,25 yang berarti berada pada level 3 (established process). Dengan berada pada level 3 maka tata kelola sistem informasi Kantor BPS sudah berjalan dengan baik dan sudah dapat mencapai tujuan bisnis instansi yang kompetitif dan efisien dalam penggunaan sistem informasi.

\section{Introduction}

Along with the times, the information system at this time is a common thing. This is because the progress of the information system and its utilization continue to increase from time to time, the speed and accuracy of information both by the business people themselves and their communities. Application of information systems in government institutions is seen as one solution that will be able to increase the level of competition. The use of information systems in a government institution certainly also brings many benefits to the government institution itself [1]-[2]-[3]. Based on the regulation of the Minister of Communication and Information Technology Number: 41 / PER / MEN / KOMINFO / 11/2007 concerning general guidelines on the management of national information and communication technology, it states that " to support the government's implementation of public services, a good information and communication technology plan is needed. (Good Governance) "[4].

The use of information systems at this time has been widely applied to government agencies; one of the government agencies in Purwokerto that uses information systems is the BPS (Statistics Indonesia). BPS itself uses several information systems, including staffing information systems that are used to facilitate smooth work. Management and accounting information system for state property (SIMAK BMN) which 
is used to conduct a census of state property. Web-based information system used to make it easier to provide information related to BPS, such as social and population data, economy and trade, agriculture and mining as well as the latest information in Banyumas Regency [5].

To find out the extent to which an information system has helped the performance of a company and to bridge the problems of current information systems with future needs that occur in the implementation of information systems governance, an evaluation is needed. Evaluation is a process carried out by someone to see the extent of the success of a program that has been planned to support the achievement of a goal [6]-[7]-[8].

According to ITGI (2007) COBIT (Control Objectives for Information and Related Technology) is a framework that can be used as a comprehensive tool for creating and streamlining the implementation of IT Governance in a corporate instantiation. Information system audits can be carried out by companies to evaluate / audit existing systems if there are deficiencies/errors in existing systems, and COBIT is used to compile and implement an information system audit model with the aim of input and recommendations for companies to improve management of information systems in the future upcoming [9].

Measurement of an information system using the COBIT 5 framework serves to measure the problem of the accuracy of the values generated by the system and the value of the effectiveness and efficiency of the process that is still lacking as a result of the system that is not integrated in order to achieve company goals [10]-[11].

Several researchers have researched in the field of information systems auditing using the COBIT 5 framework. Implementation of Information Technology governance using the training process that has been determined, and has reached the expected target, but must continue to implement Information Technology governance within the specified time limit or the time that has been predicted and must be continuously improved to meet current objectives and future [12].

With the implementation of the information system at BPS, an evaluation of the information system needs to be carried out to find out how well the information system can operate at the BPS that applies it to improve future performance. After evaluating the information system, it is hoped that BPS will be able to produce higher-quality data because this BPS data will be used by the government as a foundation for future development and as an evaluation of the results of development that have been carried out. In this study using COBIT 5, COBIT 5 was chosen because it provides a comprehensive framework that helps companies to achieve their goals and deliver value through corporate IT management and management.

COBIT 5 has 5 domains that are divided into governance and management domains, and each domain has a process that allows it to achieve its objectives. One domain comes from Governance and the other four come from management. Domains originating from the areas of Governance of enterprise IT are (Evaluate, Direct, and Monitor) EDM consisting of 5 IT processes including EDM01 to ensure governance and maintenance framework arrangements, EDM02 to ensure the delivery of benefits, EDM03 to ensure risk optimization, EDM04 to ensure resource optimization and EDM05 to ensure stakeholder transparency. In this study, the domain to be used from the COBIT 5 framework is EDM because the EDM domain is a domain that specifically determines and explains the governance process in COBIT 5. [13]-[14].

\section{Methode}

The stages of the research consisted of Library Studies, Data Collection, Data Analysis, Reporting Evaluations and Conclusions, which can be seen in Figure 1. 


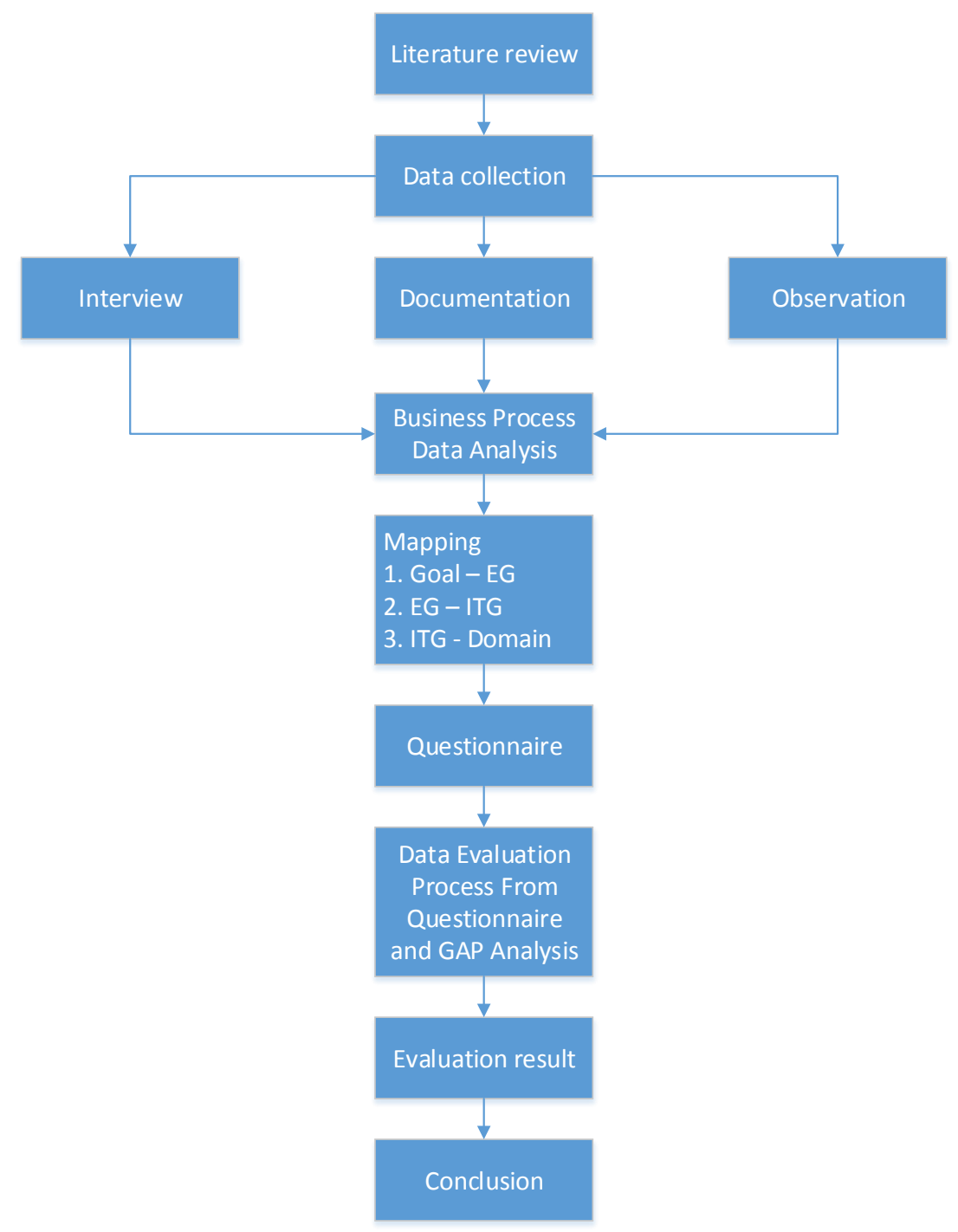

Figure 1. Research Flow

Based on the picture above, it is explained as follows:

1. Stage 1 - Literature Study

Is the first step in the data collection method. A literature study is a method of collecting data that is directed at finding data and information through documents, both written documents, photographs, drawings and electronic documents that can support the writing process.

\section{Stage 2 - Data Collection}

The data collection stage, the authors use several data collection techniques through interviews, observation and documentation. Observation is carried out with a systematic observation or activity on the object to be addressed directly using the eye senses. The interview is a method carried out using communication or question and answer to the parties concerned. The communication is carried out by question and answer in an orderly manner, both directly and indirectly. Documentation is done by taking a photo of the place of research and employees where the research is taking place.

\section{Stage 3 - Data Analysis}

At this stage, it defines the description of IS / IT and business processes currently running on the object of research. From the results of identification can be seen what the problem is. The writer will then map BPS business objectives into COBIT 5 Enterprise Goals and then analyze using the next Balance Scorecard process, identify COBIT IT - Related COBIT 5 Goals then control objectives that will be 
used by using the COBIT 5 approach for each IT process that has been defined. Then do the questionnaire step by getting a value to be processed into COBIT 5.

\section{Stage 4 - Evaluation Reporting}

After analyzing the control objectives, the assessment will be based on the capability level carried out using the COBIT 5 approach that is adjusted to the actual agency conditions. The data dissemination is done by distributing questionnaires in the form of tables given to respondents to be filled. Data collection is carried out using a questionnaire based on processes that have been selected previously. From this process, it is measured using a capability model based on the level of maturity of the institution. The result, from each process, will be taken an average rating of all processes will be compared with the standard assessment process. The assessment continued with the calculation of the GAP value between capability level and the standard assessment process obtained from the interview.

\section{Stage 5 - Conclusion}

The conclusion is a statement that contains the meaning of the conversation. The conclusion is obtained from the string of facts that occur. Thus, conclusions can be in the form of opinion sentences that generalize the facts that exist.

\section{Results and Discussion}

\subsection{Results analysis}

\section{Research Planning}

\section{a. Mapping scenario}

At this stage, the initial step taken is to identify COBIT enterprise goals, then choose those that are in line with the BPS Office's business objectives, then produce a mapping of the BPS Office's business objectives that are appropriate to the scope of the problem. Once the results of the enterprise goal mapping are found the next step will be to identify COBIT IT-related goals as well as the merging of the identification of COBIT enterprise goals with COBIT IT-related goals.

\section{Mapping}

\section{a. Enterprise Goals Goals}

At the Enterprise Goals stage, the business objectives of the project will be identified by analyzing the project initiation document. The business objectives are then mapped into COBIT enterprise goals, and then the mapping results are mapped again using COBIT IT-related goals to get the IT goals of the project following COBIT standards. The following are the business objectives of the project identified through the project initiation document:

1) Manage and protect confidential survey data.

2) Providing quality statistical data and following legal provisions.

3) Perform data updates quickly and agile.

4) Implementing regulations that are following the parties in BPS.

5) Officers who are trained, motivate the community and realize the fabric of a civilized society.

b. COBIT 5 Enterprise Goals

Mapping the Banyumas BPS Office business objectives from the project into COBIT 5 enterprise goals can be seen below:

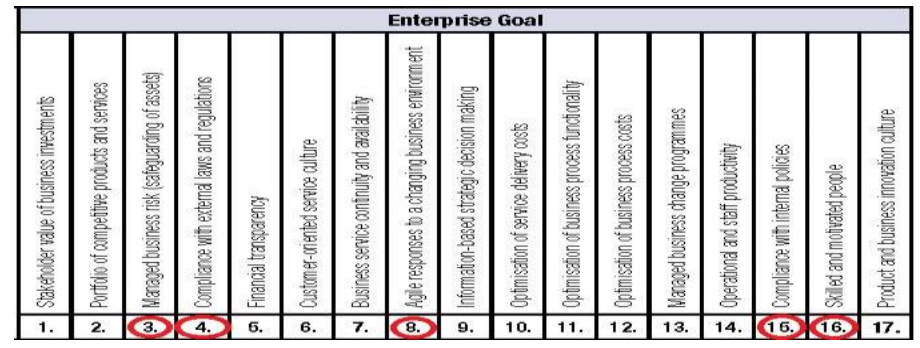

Figure 2. Mapping business goals with COBIT 5 Enterprise Goals [15]. 
1) Managed business risk (safeguarding of assets)

Manage and protect survey data that is confidential.

2) Compliance with external laws and regulations

Providing quality statistical data and following legal provisions.

3) Agile responses to a changing business environment

Perform data updates quickly and agile.

4) Compliance with internal policies

Carry out regulations that are following the parties in BPS.

5) Skilled and motivated people

Officers who are trained, motivate the community and realize the cultural order of society.

Here are the Enterprise Goals that have been selected into COBIT 5 in the table below:

Table 1. Mapping business goals with COBIT Enterprise Goals.

\begin{tabular}{|c|c|c|}
\hline 3 & Managed business risk (safeguarding of assets) & \\
\hline 4 & Compliance with external laws and regulations & \\
\hline 8 & Agile responses to a changing business environment & \\
\hline 15 & Compliance with internal policies & $\overrightarrow{8}$ \\
\hline 16 & Skilled and motivated people & \\
\hline
\end{tabular}

The Balanced Scorecard method complements management with a framework that translates missions and strategies into an integrated measurement system, namely: financial perspective, customer perspective, inter-business process perspective, and learning and growth perspective. Four perspectives in the BSC state the interrelationships to be able to describe the strategy of the agency. Relationships in four perspectives are described as a whole as below:

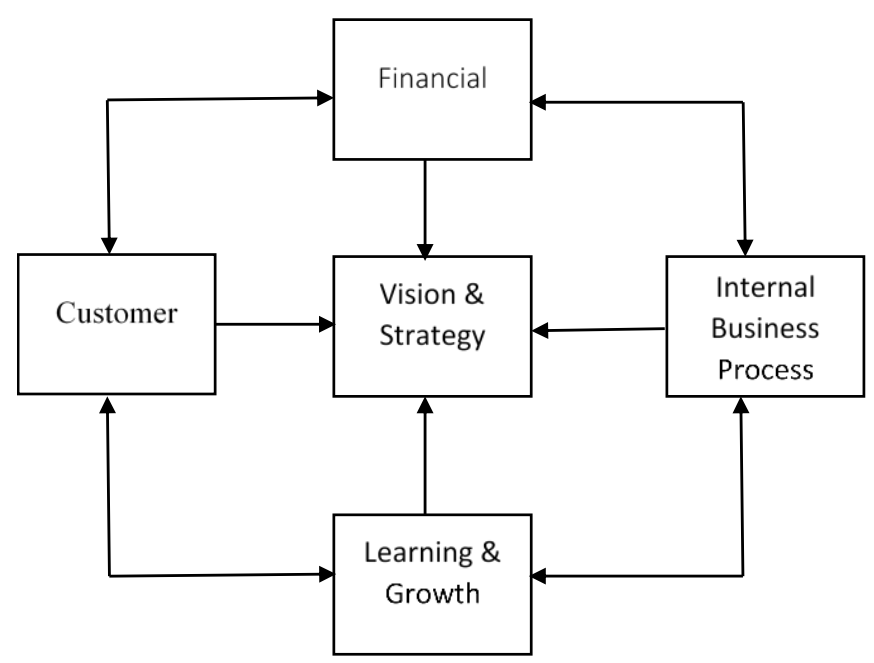

Gambar 3. Proses Balanced Scorecard [16]

BSC perspectives included in the mapping results are:

a) Internal perspective, from the mapping results above, there are 5 enterprise goals and only one is included in this perspective. This shows that they want to optimize the function of business processes in the BPS office.

b) Customer perspective, there is only one enterprise goals that enter this perspective shows that the importance of service to customers to increase the level of satisfaction with service to the community and can help create good decision making.

c) Financial perspective, there are two enterprise goals included in this perspective. The BPS Office carries out the SOP that has been determined and applies regulations following applicable legal provisions and protects confidential survey data.

d) Learning and growth perspective, the only enterprise goals in this perspective show that it is important for staff to conduct training, motivate the community and realize civilized discipline. 
The results of mapping the BPS business goals of the project with COBIT 5 enterprise goals that fit the scope are summarized in the table below:

Table 2. Mapping the business goals of the project with Enterprise Goals

\begin{tabular}{llll}
\hline No & Business objectives of IT projects & COBIT enterprise goals & $\begin{array}{l}\text { BSC } \\
\text { Perspective }\end{array}$ \\
\hline 1 & Manage and protect survey data that is confidential. & $\begin{array}{l}\text { Managed business risk } \\
\text { (safeguarding of assets) }\end{array}$ & Financial \\
2 & $\begin{array}{l}\text { Providing quality statistical data and following legal } \\
\text { provisions. }\end{array}$ & $\begin{array}{l}\text { Compliance with external laws } \\
\text { and regulations } \\
\text { Agile responses to a changing } \\
\text { business environment } \\
\text { Skilled and motivated people }\end{array}$ & $\begin{array}{l}\text { Financial } \\
\text { Customer }\end{array}$ \\
4 & $\begin{array}{l}\text { Perform data updates quickly and agile. } \\
\text { Officers who and }\end{array}$ \\
5 & $\begin{array}{l}\text { and realize the cultural order of society. } \\
\text { in BPS. }\end{array}$ & $\begin{array}{l}\text { Compliance with internal } \\
\text { policies }\end{array}$ & Internal \\
\hline
\end{tabular}

From the mapping results above, there are 5 Enterprise Goals identified:

a) Managed business risk (safeguarding of assets)

b) Compliance with external laws and regulations

c) Agile responses to a changing business environment

d) Skilled and motivated people

e) Compliance with internal policies

Where COBIT has mapped each Enterprise Goals with 4 BSC perspectives that show COBIT coverage of the alignment between a business with value and IT as an enabler.

b. COBIT 5 IT - Related Goals

Next, identify the COBIT IT - Related Goals that are appropriate for the case study. COBIT 5 has provided a mapping of each Enterprise Goals with IT - Related Goals that support, this mapping shows what IT - Related Goals contribute to the achievement of Enterprise Goals.

\section{Data Collection and Processing Phase}

1. Based on the COBIT mapping process with IT Goals and the scope of writing, 4 COBIT processes are measured capability level. In carrying out the COBIT process capability assessment process, each process is examined in stages whether the process meets the requirements that must be met at each level, starting from level 1 to 5. Also, there are category provisions from the assessment results in each level, which is a process that achieves the Largely Achieved (L) category with a range of values ranging from $50-85 \%$ or Fully Achieved $(\mathrm{F})$ with a range of values ranging from $85-100 \%$ to be able to state that the process has reached a level of capability. But if you want to continue the assessment to the next capability level, the process must first reach the Fully Achieved (F) category. A summary table of achieving capability level is formed so that the reader can easily know what level the process is at. A detailed assessment of each level is also explained so that readers can know and understand the specific conditions of each process in the BPS office. A summary template for achieving capability levels is shown in the table below.

Table 3. Summary Template for Capability Level Achievement

\begin{tabular}{|c|c|c|c|c|c|c|c|c|c|c|}
\hline Goal & \multicolumn{10}{|c|}{ Description of the purpose of the process } \\
\hline Process [process & Level 0 & Level 1 & \multicolumn{2}{|c|}{ Level 2} & \multicolumn{2}{|c|}{ Level 3} & \multicolumn{2}{|c|}{ Level 4} & \multicolumn{2}{|c|}{ Level 5} \\
\hline name] & & PA 1.1 & PA & PA & PA & PA & PA & PA & PA & PA \\
\hline & & & 2.1 & 2.2 & 3.1 & 3.2 & 4.1 & 4.2 & 5.1 & 5.2 \\
\hline $\begin{array}{l}\text { Rating based on a } \\
\text { percentage }\end{array}$ & & & & & & & & & & \\
\hline Colour-based rating & & & & & & & & & & \\
\hline
\end{tabular}


Information :

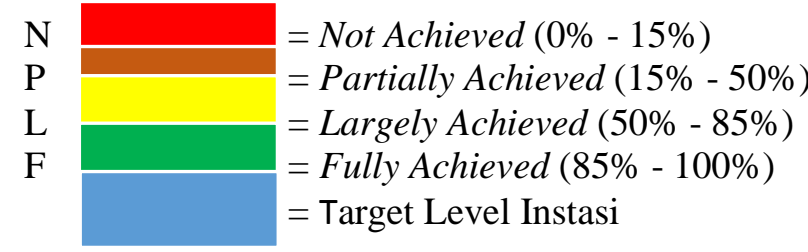

\section{Results of Capability Level Calculation}

Based on the calculation of 4 COBIT processes measured, the acquisition of capability levels that have been achieved is illustrated in Figure 4.5 below :

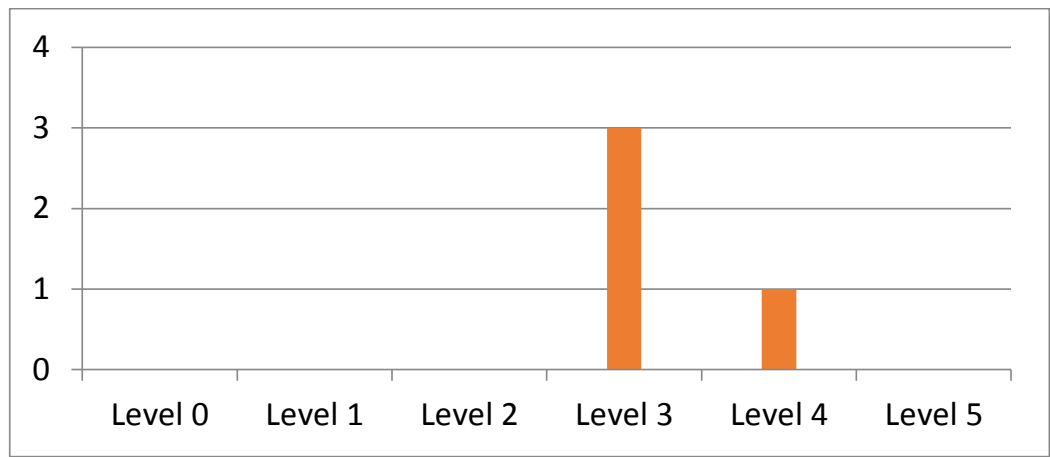

Figure 4. Capability Level Acquisition Graph

To be able to facilitate the reader in knowing the grouping of capability process levels of agencies that have been achieved based on the results of this paper, then the information can be seen in Table 4.31 below :

Table 4. GAP

\begin{tabular}{cllccc}
\hline No & IT Process & Information & Level & Goal & GAP \\
\hline 1 & EDM01 & Ensure Governance and Maintenance & 3 & 4 & 1 \\
& & Framework Arrangements & 3 & 4 & 1 \\
2 & EDM02 & Ensuring Benefit Delivery & 4 & 4 & 0 \\
3 & EDM03 & Ensuring Risk Optimization & 3 & 4 & 1 \\
4 & EDM04 & Ensuring Resource Optimization & &
\end{tabular}

GAP Analysis Profit Net Diagram

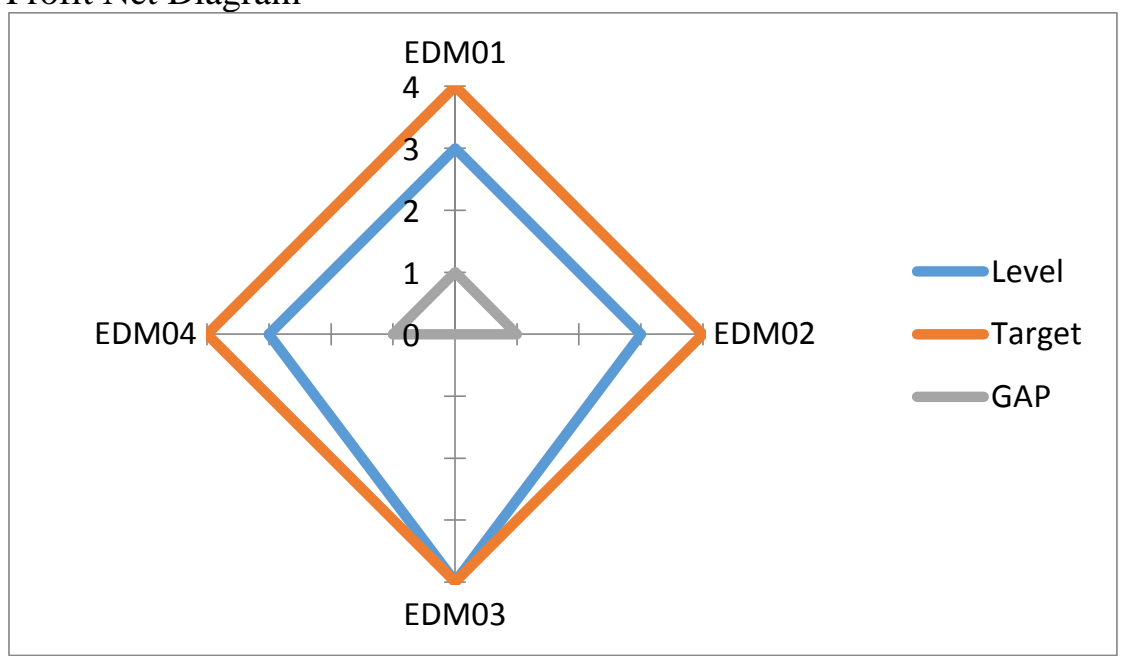

Figure 5. GAP Radar Graph 
Based on data from the capability level assessment of each process, a calculation is made to determine the average capability level that has been achieved by the IT department. The calculation is done with the average formula as follows :

Capability Level $=\frac{(0 * \mathrm{y} 0)+(1 * \mathrm{y} 1)+\cdots(5 * y 5)}{\mathrm{z}}$

Information :

$\mathrm{yn}(\mathrm{y} 0 \ldots \mathrm{y} 5)=$ number of processes in level $\mathrm{n}$

$\mathrm{z}=$ number of processes in level $\mathrm{n}$

Based on the achievement data for each process level, the average capability level calculation is as follows:

$$
\begin{aligned}
& \text { Capability Level }=\frac{(0 * 0)+(1 * 0)+(2 * 0)+(3 * 3)+(4 * 1)}{4} \\
& \text { Capability Level }=\frac{(0)+(0)+(0)+(9)+(4)}{4} \\
& \text { Capability Level }=\frac{13}{4} \\
& \text { Capability Level }=3,25
\end{aligned}
$$

From the calculation results, it can be concluded that the capability level at BPS is at the level of 3.25. In practice, COBIT does not identify process priorities that must be carried out by agencies. Priority depends on agency needs.

\section{Recommendations}

Processes that do not reach level 4 require special attention in carrying out recommendations (prioritized) along with recommendations that have not yet reached level 4.

Table 5. Recommendations

\begin{tabular}{clc}
\hline No & \multicolumn{1}{c}{ IT Process } & Score \\
\hline 1 & EDM01 Ensure Governance and Maintenance Framework & 3 \\
& Arrangements & 3 \\
2 & EDM02 Ensuring Benefit Delivery & 4 \\
3 & EDM03 Ensuring Risk Optimization & 3 \\
4 & EDM04 Ensuring Resource Optimization & \\
\hline
\end{tabular}

\section{EDM01 Ensures Governance and Maintenance Framework Arrangements}

1) Increase competence in knowing various problems or program needs that are desired as part of company standards.

2) Officers who carry out the process following their fields are competent based on education, training and experience.

\section{EDM02 Ensuring Delivery of Benefits}

1) Measurement data are analyzed to find out the causes of differences in operations so that it affects the quality of the product (goods/services) produced.

2) Take action to eliminate the undesirable situation in the company.

\section{EDM04 Ensure Resource Optimization}

1) Increase competence in knowing various problems or program needs that are desired as part of company standards.

2) Control limits are reestablished (if needed) by the act of eliminating the causes of discrepancies in data found or unwanted situations.

\section{Conclusion}

Based on the results of the evaluation of information system governance using the COBIT 5 framework in the evaluate, direct and monitor (EDM) domain, it shows that the capability level of the Office of the Central Statistics Agency of Banyumas is currently at level 3 (established process), with a value of 3.25. 
The details are that there are 3 processes at level 3 and 1 process at level 4 . By being at level 3, the information system management of the BPS Office has been running well and has been able to achieve the competitive business goals of agencies and efficient use of information systems.

Suggestions for further research BPS offices are advised to pay special attention in terms of knowing the causes of data differences in operational processes that affect the quality of products (goods/services) produced, as well as taking action to eliminate unwanted situations in the company so that everything that can trigger the occurrence of problems can be avoided and prevented as early as possible. For the next research at the BPS office, it is hoped that researchers can try to use other domains in COBIT 5 besides EDM.

\section{References}

[1] Fajrin, Rati, dkk. 2016. Perancangan Tata Kelola Teknologi Informasi di BAPAPSI Pemkab Bandung Menggunakan framework COBIT 5 pada Domain EDM dan DSS. Bandung : Universitas Telkom.

[2] Isa, Irwan. 2012. Evaluasi Pengontrolan Sistem Informasi. Yogyakarta : Grahallmu.

[3] Sutabri, Tata. 2012. Konsep Sistem Informasi. Yogyakarta : ANDI.

[4] Peraturan Menteri Komunikasi Dan Informatika Nomor: 41/Per/Men.Kominfo/11/2007. Panduan Umum Tata Kelola Teknologi Informasi Dan Komunikasi Nasional. https://jdih.kominfo.go.id. Tanggal akses 1 Desember 2019.

[5] Badan Pusat Statistik Kabupaten Banyumas. https://banyumaskab.bps.go.id/. Tanggal akses 7 Juni 2017.

[6] Burdefira. 2013. Evaluasi Terhadap Implementasi Tata Kelola Teknologi Informasi Berdasarkan Framework COBIT pada Pemerintah Kota Padang. Jurnal Pendidikan Teknologi dan Kejuruan Volume 2 No.1 2013.

[7] ISACA. 2012. COBIT 5. Self-assessment Guide : Using COBIT 5. USA : IT Governance Institute

[8] Jogiyanto dan Abdillah Willy. 2011. Sistem Tatakelola Teknologi Informasi. Yogyakarta : ANDI.

[9] ITGI. 2007. COBIT 4.1. USA: IT Governance Institute.

[10] Juliane, Christina. dkk. 2014. Pengukuran Kinerja Sistem Informasi Di PT. Rancek Sukses Bandung Dengan Menggunakan Framework COBIT 5. Bandung : STMIK AMIKBandung.

[11] Hakim, Abdul, dkk. 2014. Evaluasi Tata Kelola Teknologi Informasi Dengan Framework COBIT 5 DI Kementrian ESDM. Jakarta : Sekolah Tinggi Manajemen Informatika dan Komputer Eresha.

[12] Sari, Sepita. dkk. 2014. Penerapan Framework COBIT 5 Pada Audit Tata Kelola Teknologi Informasi Di Dinas Komunikasi Dan Informartika Kabupaten OKU. Palembang : Unversitas Bina Darma.

[13] Pranata, Ketut, dkk. 2015. Perancangan Tatakelola Teknologi Informasi di PT. Industri Telekomunikasi Indonesia (INTI) Menggunakan Framework COBIT 5 pada Domain Align, Plan, and Organize (APO). Bandung : Universitas Telkom.

[14] ISACA. 2012. COBIT 5. A Business Framework for the Governance and management of enterprise IT. USA: IT Governance Institute.

[15] Putra, Hervandi. 2014. Penerapan dan Penilaian Tatakelola Teknologi Informasi Berdasarkan COBIT 5 Framework. (Studi Kasus : BPK RI). Jakarta : Universitas Indonesia.

[16] Isoraite, Margarita, The Balanced Scorecard Method: From Theory To Practice, Mykolas Romeris University, 2008, No. 1(3), p. 18-28 